and redetermination of some forms involving very high indices on crystals examined by the late $M$. Hessenberg. The measurements were made with one of the goniometers devised by Prof. Groth, which gives definite results when the faces are good. The collimator and telescope are fixed, however, at right angles to one another, so that the determination of striated faces, such as many of those examined were, is difficult and uncertain. Much more reliable measurements would be obtained were the angle between collimator and telescope small, and it would be very easy to arrange the collimator so that the angle of incidence and reflection might be varied at will. Prof. Miller used to arrange his goniometer so that the angle between the incident and reflected ray was less than $20^{\circ}$, and was thus able to get rid of a good deal of the difficulty arising from striation.

Mr. Irby has guarded himself from error by the comparison of several independent observations of the angles made by a new face with those adjoining it, with the angles obtained by calculation, and has avoided employing the angles made with faces on more distant parts of the crystal, though the latter would be often better adapted for purposes of calculation. He criticises Prof. vom Rath's method of observation by taking the reflection of a window-bar as signal. The error which would thus arise would not exceed $I^{\prime}$ in the case of good faces, and I believe Prof. vom Rath only employs this method of observation with very good faces. Another source of error would be due to the proximity of the signal which would give a considerable error if the edge were not wellcentred. Moreover, a goniometer with vertical plane of reflection is very difficult to get into or keep in good adjustment, and errors might arise in this way. None of these errors will, however, account for the impossibility of getting simpler indices for the form $\{35,17,32\}$, considering how definite were the angles obtained from the several faces of the scalenohedron. A careful criticism of this form at the time it was published, and of all the different ways in which errors might be piled up in the course of the analysis, failed to lead to any result but that of admitting the possibility of forms with these high indices. In the Cambridge collection is a crystal of quartz with an extremely well-developed face, which Prof. Miller has determined to be $\{50,19,19\}$. It is very slightly rounded on the edge of the prism face. Of course, when the faces are rounded or otherwise distorted, indices calculated from the observations are mere approximations. Seeing the great variations which occur in the angles of wellcrystallised minerals, good work might be done in testing the constancy of the angle of the cleavage rhomb in the specimens from different localities. Breithaupt's determinations of this angle are unfortunately not sufficiently reliable.

\section{LETTERS TO THE EDITOR}

[The Editor does not hold himself responsible for opinions expressed by his correspondents. Neither can he undertake to return, or to correspond with the writers of, rejected manuscripts. No notice is taken of anonymous communications.

[The Editor urgently requests correspondents to keep their letters as short as possible. The pressure on his space is so great that it is impossible otherwise to ensure the appearance even of communications containing interesting and novel facts.]

The Molecular Velocity of Gases

YoUR correspondent, M. Hajnis, asserts in a foot-note appended to his letter published in NATURE, vol. xxi. p. 176, that "the formula for the molecular velocity (of gases) was first given by Krönig;" and not by Joule. I am at a loss to understand how this statement can be justified.

Krönig's paper appeared in 1856 , while Joule's calculation, which is that now generally received, is of date 1848 . In his discourse on molecules (Phil. Mag., December, 1873), Prof. Maxwell says : "The further development of the theory is generally supposed to have begun with a paper by Krönig, which does not, however, so far as I can see, contain any improvement on what had gone before."

R.

\section{Weaver Birds and Fire-Flies}

UNDER the heading "Natural History Notes from Burmah, in Nature, vol. xx. p. 362 of the present series, Mr. R. Romanis asked if any of your readers have ever seen or heard of weaver birds sticking fire-flies to lumps of mud on the sides of their nest for the purpose of illumination.

The tradition that certain birds of the weaver family (Floceide) and their allies do this, is prevalent over a large portion of the globe inhabited by these birds. I have traced it personally from China, all parts of India, Burmah, Ceylon, the Malayan Peninsula, Indian Archipelago, Southern, Eastern, and Western Africa, and South America. I have examined "weaver birds" nests from all these countries, and have found lumps of mud sticking inside them, and "therefore it must be true, you know !!"

But for what use are these lumps of mud stuck there?

Some years ago I wrote an article in the Cape Monthly Magazine on this very subject, entitled "Strange Stories and their probable Origin," and I started by saying "Where there is smoke there must be fire," quoting the old proverb.

My belief is that these lumps of mud are used as scrapers on which to clean the birds' bills, as I have frequently found the wing cases, and other débris of Coleoptera, \&c., fixed to them. Hence the superstition that they stick fireflies thereon, I should remind your readers that all the "weavers" are geain feeders and perhaps only occasionally partaking of insect-food, they are bothered by the bits sticking to their bills. I see my tamed birds are most careful in cleaning their beaks.

At the time I wrote my article above alluded to, I. was not so conversant with the African "hang-nests" as I afterwards became, but I can affirm that in all the places I have named the superstition, and the mud, is to be found.

British Consulate, Noumea, October 22, 1879

\section{The Papau}

Permit me to add to my friend the Rev。 S. J. Whitmee's testimony of the papau being eaten by birds in the Samoan Islands, that it is here (New Caledonia) a favourite food of the "white eye" (Zosterops), and in the Loyalty Islands was used as the only bait to attract these birds, of which dozens were brought me-of the three known species of that genus which inhabit that group (see my letters to Field newspaper) all caught by the boys through its means. If my memory serves me rightly, I have seen the papau in Mauritius eaten by a species of Zosterops.

British Consulate, Noumea, New Caledonia, October 22, 1879

\section{Scale of Colours}

IN NATURE, vol. xxi. p. I72, it is stated that at a meeting of the Zoological Society, December 2, I879, "A letter was read from Mr. F. L. Layard, F.L.S., advocating the desirability of a fixed scale of colour for use among naturalists in describing the plumage and pelages of birds and other animals." Perhaps Mr. Layard is not aware that such a scale, in form of thin 8vo, was published by Patrick Syme in Edinburgh, in 1821 , the tints being illustrated by carefully coloured examples. The exact title of the work, a copy of which is in my own library, is as follows :- "Werner's Nomenclature of Colours, with Additions, arranged so as to render it highly useful to the Arts and Seieads, particularly Zoology, Botany, Mineralogy, and Morbid Anatomy. Annexed to which are Exanples selected from well known Objects in the Animal, Vegetable, and Mineral Kingdoms." The date given above is that of the second edition, which was Printed for William Blackwood, Edinburgh, and T. Cadells, Strand, London."

Bath, December 22, 1879

L. BLOMEFIELD

(late JENYNs)

\section{On the "Habitat" of Lophiomys}

ON reading the review of "Cassell's Natural IIistory," vol. iil., given in NATURE, vol, xxi. p. 136, I find that both the anthor and the reviewer do not appear to have been aware that the "habitat" of that most interesting rodent, Lophiomys imhausi, is 